\title{
O PAPEL DA INVENÇÃO RETÓRICA NA POLÍTICA CRIAÇÃO ARTÍSTICA COMO FUNDAMENTO PARA UM FUTURO \\ PROGRESSISTA
}

Plínio Ubiratan Figueiredo Vieira ${ }^{1}$

\begin{abstract}
Resumo
Disserta-se a propósito da invenção retórica como propedêutica política. A invenção artística compete com a imitação e a emulação, movimentos saudosistas tradicionais e de conservação. O papel progressista da arte está em projetar subjetividades para a vida social e isto implica formação de ética, lógica/comparativa e emotiva fora do convencional. Eis um provável cerne da base progressista e da resistência popular.
\end{abstract}

\section{Palavras-chave}

Invenção retórica. Arte. Política.

\section{1) De que retórica se fala}

A retórica que se expõe neste artigo não se confunde com oratória (arte de falar em público), passo posterior à dialética (arte de falar com um interlocutor), mas abrange o pensamento (arte de falar consigo), a dialética e a fala em público - trata de saber sobre discursos.

Esta retórica também não se opõe à lógica, composta por sofismas artificiosos (lógica ou retórica), mas inclui a lógica epistemologicamente, acrescendo-lhe o método comparativo, por semelhança, para lidar com a perspectividade do conhecimento humano. Ou seja, o que se deduz/induz pode se deduzir/induzir originalmente do outro e não só de si. Disso, não se separa do discurso sua partida ética - quem fala, de que ambiente gregário e com quais valores; nem seu destino emotivo - a quem se volta o discurso, em qual ambiente e com quais valores. Lida-se com o que Perelman chama de dupla hierarquia - não só pensar em termos de quantidade, mas também de qualidade (PERELMAN, 1997, p. 14). Não é, portanto, ciência exata, mas conhecimento aproximado.

Nesta retórica, em uma disputa política, almeja-se expor proposições, demonstrá-las, por relações apodíticas naturais ou estabelecidas artificialmente por acordos, e também argumentá-las a partir da ampliação assertiva do útil (política),

\footnotetext{
${ }^{1}$ Mestre em Filosofia (IFCS - UFRJ); bacharel em Direito (FND - UFRJ); bacharel em Comunicação Social, Jornalismo (UNESA - Niterói). Atua como advogado (consultoria e contencioso), pesquisador e escritor. nas Áreas da advocacia: constitucional, trabalhista, penal, administrativo, consumerista, contratos e obrigações. Áreas da filosofia: ética, epistemologia, filosofia política e filosofia do discurso (retórica).
} 
justo (direito), laudatório (ética) e belo (estética), e redução do nocivo, injusto, vituperado e feio, a fim de haver deliberação, juízo acerca de discurso, do falante e das emoções envolvidas.

Decerto que nesta retórica há três pontos onde um discurso pode se concentrar. O primeiro enfoque é a ética, ou concentração em um grupo e seus costumes de onde partem autor e obra (éthos); o segundo é a lógica e a comparação, enquanto o discurso concentra-se em mostrar termos gerais que se relacionam com fatos e feitos particulares, e na comparação parametrizada e exemplar de fatos e feitos, para fazer juízo de valor hierárquico ou de igualdade acerca deles. Sim, há cores nesta retórica (lógos); o terceiro é a emoção/afetação, um discurso que visa a agradar ou a criticar e que pode ser recebido com elogios ou vitupérios (páthos) (ARISTÓTELES, 2011, p. $45^{2}$ ). Pode-se intentar dissociar um do outro (MEYER, 2007, pp. 30-31), mas nesta retórica há uma "logética" ${ }^{3}$. Isto é, há uma conjuntura corpórea, não ideal, indissociável entre ética, lógica e analógica, e emotividade. E a diferença entre um discurso e outro é o enfoque e grau em um destes três itens, e possíveis reduções ou negações de um ou dois dos outros focos.

Antiético, dessa forma, pode ser considerado aquele que torna essencial a seu discurso a destruição de um éthos ${ }^{4}$ outro, que não o próprio, e pode buscar argumentos científicos que justifiquem a antiética (como se fez com uso de argumentos deterministas de distinções de raça, por exemplo). O emotivo ou afetado pode ser considerado pouco ou nada racional ou de valores éticos pouco repercutidos (pobre em ética e lógica), ou pode ser conforme costumes e valores, mas irracional (discurso feito para agradar - tem ética, não tem lógica, tem comparação, tem afetação). Mas um discurso emotivo também pode convergir com o ético e/ou o racional (ter ética e lógica). Ou seja, repele-se aqui o discurso simplista, de secções ideais que extrai apenas o saber e a técnica como objetividade. Pensa-se a ignorância da subjetividade e da emoção para a conveniência de discursos que se dizem lógicos, mas estão numa linha de costumes específica e dotados de alguma vontade, mesmo que esteja alhures.

Note o leitor o seguinte, o estudo da retórica, diferente de métodos científicos e filosóficos tradicionais, inclui dois campos que são costumeiramente excluídos nos

2 Cf. 1356a1-9.

3 Na falta de expressão mais adequada, este autor sugere o uso improvisado do termo logética (lógos + éthos, que envolvem/são envolvidos por páthos).

4 Neste artigo, a fim de proporcionar leitura mais fluida, serão usadas as palavras nicho, costumes, princípios, valores para substituir éthos, as palavras lógica e analógica/comparação, para substituir lógos, e as palavras emoção, vontade, afetação e romantismo para substituir páthos. 
discursos profissionais: o ético e o emotivo. O ético costuma ser excluído para dar aparência de neutralidade ao conhecimento, embora todo aquele que produza um conhecimento venha de um ambiente gregário e que dele, ou de outro eleito no curso da vida, traz, inevitavelmente, um gênero específico de experiência possível, ou recortes tópicos e argumentativos ora mais ou menos sincréticos. Ou seja, o saber contém tipos de preconceitos e o que faz parecer menos preconceito é o fato de que se assentou como analítico por algum tipo de acordo, convenção social, ora posto como algo esperado, provável de ser. O emotivo é classicamente posto como problemático, pois é objeto filosófico de culpa pela má compreensão do humano acerca da razão. Compreende-se mal porque o sentimento, a vitalidade sensível, impede de ver a verdade racional - afetações e razões seriam mundos seccionados, distintos e logicamente excludentes. Na retórica se reconhece que não há conhecimento humano sem vontade. Pode até haver o imparcial, quando aquele que faz juízo não tem vontade alguma particular acerca do objeto decidido, mas há uma vontade representada, vinda de alguma subjetividade artística, que é costumeira ou normativa. Num nível mais pessoal, íntimo, basta haver um fato de vida que toque a emoção do juiz, para que se forme um viés emotivo. Nada obsta que a decisão emotiva e a racional sejam a mesma coisa, no entanto. Ou seja, a exclusão entre razão e vontade é classicamente uma falácia simplificadora retórica, sob um argumento formal lógico, inventado artisticamente por humanos.

Ainda há de se falar em uma perspectividade, que não é um relativismo, visível que o sentimental do outro pode ter razões outras e serem plausíveis, embora excluíveis por um grupo valorativo maior ou mais poderoso. Quanto mais solipsista ${ }^{5} \mathrm{o}$ pensador, mais parece se fundamentar em ética, razões e emoções individuais, mais cerrado em favoritismos poderá permanecer. Tanto quanto mais comunitário plural, mais logética terá condições de conhecer e considerar válidas diferenças, no que não forem contraditórias no cerne. Assim, na retórica, o conhecimento se desenvolve por uma logética - o que implica depreender sentido, nexos, liames entre sujeitos, ações, objetos, lugares e tempos. Há uma relação inseparável entre ética, lógica e comparação, e emoção, não sendo possível, senão por uma analítica ideal, separar aquele que produz conhecimento humano de seu senso ético e de suas afetações. Este processo pode ocorrer nos três auditórios de Perelman (PERELMAN, 2019, pp. 34-

5 Método executado por se pensar sozinho, individualmente. Examinar, em pensamento, o próprio eu e objetos externos, com elevado ceticismo diante dos objetos externos. 
50): do sujeito consigo mesmo - pensamento; do sujeito com um interlocutor, ou mais interlocutores - dialética; ou do sujeito com apenas ouvintes - oratória.

Esta retórica se apresenta como conjunto conceitual e operacional, que capacita o estudante a análises de discursos e no saber sobre o fazimento deles. Chame-se de uma filosofia regressiva do discurso, pois seus conceitos são perenes (estudados há cerca de 2.500 anos) e contemplativos. E chame-se também de uma arte do discurso, pois seus conceitos e técnicas capacitam ao fazimento de discursos originais e tão capazes de serem excelentes quanto os já existentes.

\section{2) Subdivisão de um discurso retórico}

Um discurso retórico costuma ser subdividido em cinco partes (PSEUDOCÍCERO, 1997, p. $71^{6}$ ), (CÍCERO, 1896, p. 178; p. 1937): invenção, disposição, estilo, percepção ${ }^{8}$ ou memória (PLEBE, 1978, p. 66) e ação. A invenção consiste na introdução de um tópico, do estado da arte, do(s) problema(s), das hipóteses de definição, argumentação, das relações de associação e dissociação, das noções de causa e consequência e as propostas de solução. A disposição consiste na montagem do discurso, o que vem em que ordem processual e porque deve ser assim. O estilo se pronuncia pela linguagem imagética e/ou sonora, e a escolha do tipo enunciativo (acadêmico, histórico, artístico hipócrita, poético, chistoso, parabólico, fabuloso entre outros). A percepção (que no exato curso de um(a) pensamento/fala viva costuma ser chamada insight) implica o raciocínio sobre o conhecimento acumulado e a descoberta, ou invenção, de um novo conhecimento por duas ou mais inteligências (informações em memória ou recebidas num momento instantâneo) associadas ou dissociadas. Assim, é notável também que a percepção contém uma velocidade de processamento. Chame-se de raciocínio. A memória implica o conhecimento acumulado sobre o tópico proposto, chame-se de inteligência. Por fim, a ação se trata da apresentação executiva do discurso por um canal. É ato artístico que demanda experiência, como autocontrole para pensar consigo, falar com outros e falar em público, com uso da fala

6 Cf. I $2,3$.

7 Cf. I XXXI, XLII.

8 Segundo Plebe, tratadistas estoicos traziam em sua retórica o conceito de noésis, um faro pensante, percepção. Em Retórica a Herênio, de pseudo-Cícero, a percepção é substituída pela memória, um dom técnico de ter de cor o tópico e os argumentos organizados, para serem escritos ou falados. A abordagem estoica implica conhecer intuitivamente, conhecer por pensamento voltado a um objeto. É método filosófico de raciocínio. A abordagem em Retórica a Herênio se fundamenta em memorizar conteúdo e argumentos (ideias e palavras à disposição), por dom (virtude da boa memória) ou método técnico (de imitação, repetição, ensaios etc.). 
viva, escrita ou imagética. Neste artigo, embora a exposição completa talvez seja útil ao estímulo da arte discursiva do leitor, será abordado apenas o papel da invenção no saber humano e no que se relaciona com a arte humana e a política.

\section{3) Invenção, emulação e imitação e os tempos sociais e políticos}

O primeiro tópico a ser abordado é uma necessária expansão da invenção retórica. Propõe-se que o que a invenção seja acompanhada por duas outras coisas: emulação e imitação, aqui com uma inspiração remota nos conceitos de imitação e emulação de Pseudo-Longino (2007, pp. 49-509).

A invenção traz algo mais novo e diferente sublime do que o que já existe. É o que ocorre na ciência extraordinária, de Kuhn (1998, pp. 127-128; pp. 166-167; p. 172-173). Autores que inauguram linguagens e formas de pensar são exemplos. Como analogia, é uma semente que se vê crescer em uma árvore de fina estética, cujo gozo do olhar provoca profundo sentimento humano, e cuja utilidade para a vida se encontra de variadas maneiras. A emulação consiste em fazer médias e pequenas inovações em uma linha de pensamento que já existe. É o que ocorre na ciência normal, de Kuhn (1998, pp. 71-72). Comentadores de autores servem de exemplo. São os ramos que crescem de uma árvore e a partir dela geram inúmeros frutos, sem contrariar o recorte genealógico dado. A imitação, por sua vez, consiste em cópia, tradição, massificada. Por comparação, aplique-se este saber não só à ciência, mas à arte. Serão encontradas as cópias massificadas, as obras inspiradas e, por fim, as obras com novidades. Esta ideia também pode ser aplicada à política. Há uma vontade de regresso político: por imitação; outra de conservação: agir por emulação com pequenas mudanças contingentes; e outra de progresso: agir por emulação, com pequenas mudanças essenciais, mas principalmente por invenções, com revolucionárias mudanças capazes de alterações políticas substanciais.

Os três tópicos mencionados encontram repercussões éticas, de compatibilidade e incompatibilidade costumeira e valorativa, e emotivas, de agrado ou desagrado afetivo. Pode-se dizer, por exemplo, que a imitação, enquanto ética, está na formação ética social, seja maior ou menor o grau disciplinar: na vida gregária livre, na escola, no quartel, nos ambientes de ofício em geral. Atrela-se também à moral, pois é discurso tradicional, que é entregue de pais para filhos. Atrela-se, por fim à

9 Cf. XIII 2. 
emoção, por recebimento passivo, afetado das ações sociais. Como emoção e romantismo, sem fundamento argumentativo, a imitação pode ter um nicho ou ser de massa - gostar ou não gostar de algo ou de alguém por não ser da própria turma, ou algo ser para "todos" os gostos. Quando de massa, precisa ser algo simples, fácil de ser reproduzido e de ser pouco explicado. Em um discurso, por exemplo, esta imitação patética (páthos) é muitas vezes disposta com fundamento místico, para ser replicada popularmente sem grandes argumentos verificáveis, mas, sim, se calca em causalidades supersticiosas, no medo e na obediência acrítica (religião) e no entorpecimento do senso crítico ou na violência contra tal senso (ideologias autoritárias).

$\mathrm{Na}$ arte, o desenvolvimento inventivo é espontâneo. O sujeito tem “incondições”. É livre para pensar, criar um nicho ou para se incluir em um de vários nichos. Pensa, põe ou vê no mundo um fragmento substancial da abstração de si. Isto pode agradar o emotivo, formular um éthos artístico em espécie e uma técnica artística em espécie. Disso, se desdobra que a invenção implica pensar tanto dentro da experiência possível quanto fora dela. Pensar/imaginar o ordinário e o extraordinário. Escapa ao exercício de razão formal dedutiva - quer dizer, escapa do intento de se descobrirem ou de se criarem modelos a serem seguidos forçosamente pelas mais diversas substâncias, que podem ter seus próprios modelos a serem criados validamente, por esponte própria. Isto é, capacidade de se conhecer e de se inventar com liberdade, conforme as próprias afetações. O "erro" de substâncias fora do modelo não é necessariamente não possuírem uma forma, mas serem diferentes em termos de identidade de nicho, de razões e de afetações. Assim, há um pensamento que se projeta como predominantemente analítico, dentro da caixa, e outro que se projeta como dialético, fora da caixa. Esta dialética entre o dentro e o fora são semente para problemáticas políticas, numa indução das diversas bases populares para o seu lançamento como movimentos/forças políticas de regresso, de conservação ou de progresso.

\section{4) Natural e artificial - descoberta e invenção}

O saber humano se ampara em uma relação de grau entre o natural e o artificial. Imagine o leitor um espectro em que há assuntos autoevidentes, outros afirmativos, e outros, ainda, duvidosos. Neste espectro, cada tópico discursivo de saber se insere mais em um gênero do que em outro. Por exemplo, acerca do tópico vida ou morte, há 
conteúdo autoevidente natural. Pois é certo que o que vive, morre. E não é preciso verificar externamente, a cada vez, em cada lugar, se o humano vai morrer ou não. $\mathrm{O}$ mesmo pode se dizer da natureza da manutenção da vida. É preciso se alimentar, beber água, é preciso manter a temperatura corporal e realizar um trabalho de cuidado de si para isso. Não há alternativa, não há margem para inventar. Há coercitividade acerca de tais tópicos, pois são assuntos naturais. Toda a espécie humana se deduz destas características imóveis. Por ser de núcleo natural, aquilo que se desvela sobre a vida, a saúde, em biologia, química, é descoberta, não invenção.

Em um outro sentido está aquilo que não é coercitivo, senão por acordos sociais que permitam encontrar um resultado apodítico artificial ${ }^{10}$ ou assertório ${ }^{11} \mathrm{e}$ substituir consequências naturais por fiscalizações e correções artificiais. É o caso da aritmética, que por linguagem numérica permite que qualquer sujeito, em qualquer tempo e lugar do mundo encontre o mesmo resultado. Mesmo na aritmética há um acordo de hierarquia de valor. Diferente da convenção de letras ocidentais, na aritmética não se prioriza o sentido da esquerda para a direita, mas por certas operações. Porém, não há nada no mundo que force, controle, de maneira natural, esta constituição hierárquica de que as coisas se multiplicam primeiro e depois se somam. Há criação artificial humana, via da qual se produz uma verdade convencionada. Daí, algo que é dialético, discutível, se firma como analítico, pouco ou nada discutível, em razão dos critérios estabelecidos/conhecidos. Se é dessa forma, artes inventivas solucionam estados de aporia ${ }^{12}$. Se com a aritmética é possível tal demonstração de transmissão de convenção simbólica hierárquica, nos assuntos humanos, os acordos artificiais são regra e os assuntos apodíticos são excepcionais no espectro do

10 Autoevidente, que se demonstra por silogismo coercitivo, mas apenas de modo formal. O controle substancial da forma pode ou não ocorrer, daí a artificialidade. Por exemplo: boletos vencem dia 10 , sob aplicação de multa, sem exceção. Platão paga um boleto depois do dia 10. Platão é multado. Vejase, o futuro de quem não pagar o boleto até o dia 10 é, certamente, ser multado. Embora não haja nenhuma força natural que force o pagamento da multa, como um termo natural de morte, que encerra certamente a vida. É necessária alguma humanidade, artifício, para garantir, fiscalizar, a cada vez, o acordo coercitivo - norma, sanção e garantia de cumprimento.

11 Asserir significa afirmar. Há uma afirmativa proposta como lógica, mas não é autoevidente. Embora uma afirmativa possa ter forma lógica silogística, pode não ser substancialmente lógica. Assim, se deseja se evitar o exercício de preconceito ou de prejuízo, uma verificação externa é sempre imperativa. Por exemplo: matar é proibido por lei. Sócrates matou (enquanto hoplita). Sócrates violou a lei. Veja-se, se Sócrates matou inimigo em guerra, provavelmente não infringiu a lei. Dessa e de outras maneiras, há variadas situações concretas em que um silogismo poderá não ser conclusivo. Enquanto afirmativo, expõe apenas uma razão esperada. Informa um acordo afirmativo geral - norma, mas incerto até inspeções de fatos e feitos possibilitarem conclusão. A lógica formal pode ser, portanto, uma quase-lógica. Pode intentar ser analítica, mas não elimina a dialética por completo.

12 Situação de dúvida, indecisão, ambiguidade, impasse acerca de opiniões racionais capazes de responder a certas questões. 
conhecimento. Por serem de núcleo majoritariamente artificial, os assuntos humanos contêm mais invenções do que descobertas. A política intenta legitimar o fim da dúvida por meio de normas, a fiscalização se dá pelo poder executivo, e a justiça acerca dos acordos se faz pelo judiciário. Eis o funcionamento institucional em ciclo.

\section{5) Arte, ciência e filosofia}

Por definição, arte é um saber fazer. Conhecem-se os insumos e procedimentos, a fim de que se chegue a um produto final, em certa quantidade e/ou de certa qualidade estimável ou a estimar. Ciência é saber de rigor, tempestivo, progressivo conforme tecnologias espirituais, de pensamento, e materiais, de suporte experimental físico e de ampliações sinestésicas. Filosofia é algo complexo de se definir, pois há dois sentidos filosóficos, conforme o objeto filosófico. Chama-se de filosofia primeira a que se fundamenta no divino ou em metafísica como objetos primeiros, que vêm antes de tudo e de todos (ARISTÓTELES, 2012, pp. 43-47 ${ }^{13}$ ). Chama-se de filosofia regressiva a que se volta ao humano no limite do recorte estudado, fazendo-se uma regressão, uma engenharia reversa, uma genealogia de fatos e feitos, das relações causais e do que se associa e dissocia, para uma analítica do que se pensar no presente e no futuro, e orientar quais alternativas do saber/fazer há quanto ao tópico. Propõe-se algo mais simples para esclarecer aqui o que é filosofia: trata-se do estudo de ciclos naturais e artificiais, que se repetem com certa exatidão em termos de fatos e feitos, e que deles decorrem relações de causa e consequência certas ou prováveis. Assim, é possível uma intelectividade e um raciocinar sobre o que ocorre no presente e uma futurologia ${ }^{14}$. Além disso, a filosofia se distingue da ciência porque seus conceitos buscados são eternos e universais, para a primeira, ou perenes e territorialmente amplos, para a regressiva. Isto é, quando se estuda um tópico filosófico, se é filosófico, deve ser possível voltar a ele em termos de conceitos em qualquer lugar do globo, de modo intempestivo, ou daqui a pelo menos mais umas centenas ou milhares de anos.

13 Cf. 981b25-983a24. De maneira bastante resumida, Aristóteles propõe uma hierarquização de saberes, na qual o homem com experiência é mais sábio do que o que tem apenas as faculdades sensoriais, o artista é mais sábio que o homem da experiência, o mestre, mais do que o artesão, e, como as ciências especulativas são mais ligadas ao saber do que as produtivas, aquelas vêm no topo. Sendo assim, a sabedoria seria conhecimento elevado, de certos princípios e causas.

14 Um dos objetivos principais da filosofia e das ciências é a previsão do futuro e preparação conforme. A diferença entre o oráculo e o sábio/cientista está na passagem das causalidades supersticiosas (obscuras) para causalidades intelectuais e materiais (verificáveis por qualquer humano). Disso, na política se discute sobre duas ou mais previsões do futuro da vida pública, quais melhores opiniões sobre como agir e como deliberar acerca delas. 
Estudos filosóficos não estão, finalmente, atrelados ao uso de tecnologias passageiras, o que ocorre nas ciências.

Uma das grandes dificuldades para que a filosofia regressiva seja considerada filosofia é o fato de que não é filosofia pura, mas interdisciplinar. Anda misturada com a história, a psicologia, a sociologia, a política, o direito, a arte. Uma filosofia considerada pura é necessariamente dedutiva daquilo que o pensador "descobre" em investigação através do que está obnubilado pela física, está além da física. A frônese, conceito aristotélico para sabedoria prática (ARISTÓTELES, 2014, pp. 225-228 ${ }^{15}$ ) não é classicamente considerada saber nem arte, pois é virtude (dom pessoal) para a ação de ter boas opiniões e de fazer boas deliberações. Não é ciência, pois não lida com o necessário (autoevidente, imóvel), mas com o mutável (duvidoso, afirmativo, móvel). Aristóteles era filósofo primeiro, mas, na filosofia regressiva, a sabedoria prática é parte fundamental para o desenvolver do conhecimento humano. Pois um humanista não se contém em lidar apenas com o essencial/perfeito/divino que supostamente há além da física, ou com uma intelectividade gênica exata, mas precisa lidar com artifícios humanos e antever futuros prováveis, esperados. Precisa extrair razões de uma vida conjuntural, mista, em que as pessoas, coisas e ambientes estão suscetíveis à mobilidade. A frônese se torna meio contemplativo e técnico para uma arte, uma coletânea imitativa, emulativa e inventiva para um savoir-faire não só do agir, mas do contemplar de razões e deliberações do artista. A sabedoria prática na filosofia regressiva torna-se condição existencial artística humana num mundo físico não laboratorial. O futuro, embora não seja precisamente previsível quanto o é no científico exato, pode ser esperado, aproximado e oportuno ${ }^{16}$. No saber humano também se lida com um mundo do "ser" e "estar", não somente do "ser", "não ser" e “dever ser". A sabedoria prática numa filosofia regressiva fundamenta o pensamento e a arte sobre si - uma sofrosine, por autoconhecimento e cuidado de si; a dialética - no conhecimento e cuidado dos outros; e no entendimento da ética, valores e afetações esperadas de um auditório abstrato - nas publicações de si. Cantou Seixas que é preferível ser uma metamorfose ambulante, do que ter aquela velha opinião formada sobre tudo. O que se tem para dizer é que tanto nas ciências quanto na filosofia o conhecimento de uma matriz artística, emulativa e inventiva, é relevante para se compreender atos de movimento. O que é da ciência sem invenções técnicas e o que é

15 Cf. 1140a24-1140b31.

16 O esperado (eikós) e o oportuno (kairós) serão abordados mais adiante. 
da filosofia sem invenções artificiais que capacitem variados esclarecimentos ao ato de pensar? E o que é da arte discursiva, sem o filosófico e o científico?

\section{6) Da transitoriedade entre analítica e dialética}

Aqui se discursa sobre a invenção e as transições cíclicas de dialética, situação de diálogos sociais e políticos (aporia, dúvida, disputa), para analítica (resposta se encontra por ciência natural, ou acordo artificial é estabelecido via ciência humana e/ou por simples vontade de quem detém poder).

Imagine o leitor um espectro em que há uma relação de disputa entre analítica e dialética originada em diversos movimentos sociais. São forças políticas, que entram em processo agonístico mais ou menos civilizado. Problemático ou político se diz de um assunto em que o duvidoso é maior do que o assertórico ${ }^{17}$ (MEYER, 2018, pp. 34-35) e o apodítico. Há pouca convenção e baixa certeza natural. Duas ou mais opiniões entram em agonística (estado dialético) pelo que é o mais útil e menos nocivo, até que haja informação e raciocínio (estado analítico), e vontade (querer de quem detém poder), para encerrar o estágio de aporia.

Há, nesta competição, um ciclo filosófico de estabilidade e movimento de postura das pessoas, coisas, objetos, lugares e tempo (simbólico, pois há subjetividades fora de seu tempo histórico, no passado, no presente e no futuro regressistas, conservadores e gente à frente do próprio tempo). O que se quer dizer é que, a partir da invenção, da emulação e da imitação, ou há um esforço pela analítica humana, aparente imobilidade, ou pela dialética humana, mobilidade. Não há, senão em assuntos estritamente autoevidentes, essencialmente naturais, imobilidade eterna. A arte inventiva, lidar com artifícios da humanidade, muda não só o patético, o emotivo, mas a essência lógica e comparativa, forma profunda de pessoas e coisas. É capacidade de pensar e fazer o mundo fora de seu ser e fora de seu tempo, e nisso encontrar um sentido ético, lógico/comparativo e emotivo. A emulação consiste em pensar o mesmo, o ordinário, com adições recicladas ou com poucas doses de algo novo. E a imitação, em termos de arte, sendo epidítico, mas não injusto, é a mais

$17 \mathrm{O}$ que se afirma com fundamentona divisão de problematicidade dos gêneros retóricos, proposta por Michel Meyer: (i) o gênero deliberativo, ou político, tem problematicidade máxima (questão duvidosa, sem critério de solução); (ii) o jurídico tem problematicidade grande (questão incerta, mas com critérios de resolução); (iii) o demonstrativo ou epidítico tem problematicidade fraca (questão resolvida). 
pobre de todas. Imitações contêm respostas prontas para a minoridade usar. Kant diria: “Ouse saber!", este autor diz: Ouse fazer arte!

Classicamente os métodos de exatas servem de paradigma para ciências humanas ${ }^{18}$, mas a linguagem simples dos números, a lógica pura e a secção de objetos em partes não estão a salvo de movimentos conjunturais práticos da vida mista, real. É aí que se percebe que o ideal laboratorial funciona em condições ideais e a teoria se dissocia da prática de tal forma que acaba sendo meramente disciplinar (BACHELARD, 2008, pp. 136-141). Para que uma teoria puramente lógica funcione, precisa disciplinar o ser. O "dever ser", a estipulação de princípios orientadores e a disciplina corpórea estão na formação das ciências desde iluminismo. O problema epistêmico está, no entanto, em desvendar falácias sociais e políticas das formas dadas, que tacham previamente incompatibilidades com a ética e com os afetos modelo. Tais formas padronizadoras eliminam, de plano e sem fundamento substancial, concreto, toda ética e emoção que não forem as de uma massa obediente à política dedutiva. Quando a política se figura, retoricamente, com a mesma forma metodológica de ciência ou de filosofia analítica, visa a fazer-se parecer tão analítica quanto, para eliminar qualquer chance de diálogo, mesmo que existam tópicos e conteúdos reais que demonstrem tal chance. Os próprios exercícios da lógica pura se convertem em antiéticos e antipáticos. É vida que se vive sem origem (o humano sem éthos, sem lugar definido na história e no tempo) e sem a compreensão das cores das vontades do si e do outro (o ser antipático). Sumarizam-se todos a gado medíocre, cujas intencionalidades deveriam ser trabalhar, pagar tributos, obedecer ao Estado, reconhecer, caçar (e até mesmo ser capaz de matar, como se uma força natural fosse) os recalcitrantes.

Aqui está, de uma forma bem resumida, a surpresa de que o progresso científico conduziu às barbáries vistas no século XX. Se a humanidade se move progressivamente, como foram possíveis tais atos anti-humanos? Uma resposta suficiente se encontra pela seguinte proposta: um saber puramente lógico dedutivo aplicado a humanidades cria um dilema entre forma e substância. Pois a forma visa a

18 Embora se intente fazer a adaptação matemática, há diferenças na relação de assuntos autoevidentes, assertóricos e duvidosos nas ciências humanas e nas da natureza. Diz-se científico humano o assunto em que o assertórico e o apodítico são maiores, nesta ordem, que o duvidoso. É o caso da economia, do direito, da sociologia, da psicologia e até da medicina, quando em processo de descoberta. São ciências meio, não fim. Diz-se científico exato o assunto em que o apodítico é maior que o assertório e o duvidoso. Científicos exatos são os assuntos das ciências matemáticas e da natureza, com baixa ou nenhuma margem deliberativa. 
moldar substâncias que já têm sua própria forma e que são ignoradas ou marginalizadas. Há uma perspectividade a ser notada, uma dupla via, dialética. Pois a forma que deduz encontra eventualmente substâncias que a ela resistem. E a substância objeto pode ser de tal forma resistente e artística, que é capaz de rachar a forma impositiva em sua própria substância.

\section{7) Subjetividade e objetividade}

Há duas perspectivas acerca da formação de verdade: uma vinda da descoberta e outra da invenção. A verdade descoberta encontra-se como algo atrás dos empecilhos físicos, implica o desvelo definitivo, universal e eterno de uma norma antes oculta ao intelecto. Assim, na soma de informações e por uma sucessão raciocinada disciplinada por um método, a mente chegou à descoberta final acerca do objeto ao qual se volta. Dessa maneira, há uma verdade "divina”, motor essencial que põe pessoas e coisas em movimento. Qualquer pesquisador que acertar no objeto e no método adequado, em qualquer tempo e em qualquer lugar do mundo, chegará a mesma resposta, pois a verdade é a mesma, única ou de baixíssimo grau alternativo. Chamou-se, e alguns ainda chamam, esta caçada ao tesouro humano de objetividade. Então a subjetividade poderia ser ignorada, pois afetações e decorrências sensoriais estariam a atrapalhar a rota racional ao conhecimento. Razão excluiria ética e emoção, tudo seria descoberta, nada seria invenção. A outra verdade é a artística, ou seja, as normas são criadas por homens e não descobertas na natureza. A maior parte do conhecimento humano é inseparável de uma ética e de vontades abstraídas em uma lógica da maioria culturalmente dominante. Há uma subjetividade que é normalizada como objetiva.

O grande debate em torno destas verdades artísticas se dá pela localidade e efemeridade das hipóteses e teses, pois são "mortais" como o corpo físico. Não são universais e atemporais, mas degradam-se. A questão, ou desafio artístico é, portanto, o de abrangência e de perenidade. Não só para compreender a subjetividade outra e adaptar o discurso a ela, em psicagogia ${ }^{19}$ (PLEBE, 1978, pp. 4-6), mas também no

19 Condução de almas. Na prática significa alteração da disposição do ouvinte ou de leitor de um discurso. Fazê-lo mudar de opinião, inclusive incutindo-lhe, antes, uma capacidade de mudar de opinião. Esta mudança pode se dar por identidade de valores, virtudes ou princípios (éthos); por discurso racional, com método dedutivo, indutivo e comparativo, com indícios, provas e juízo (lógos); por identidade de vontades, de estímulos emocionais e de afetações compartilhadas (páthos). A arte discursiva move ou imobiliza. Serve para o agir ou para o omitir. A psicagogia pode se efetivar com 
lançar a própria ética e a própria emoção para a agonística, a competitividade social. E, conforme visto, a competitividade dialética ora se assenta, por processo mais ou menos bárbaro, em analítica. Logo, nessa forma de verdade, o papel daquele que faz o conhecimento importa, enquanto experiência e percepção ética e relato de vontade de lançar obra ao conhecimento e às vontades outras. A subjetividade humanista importa à política, ao direito, ao ético e ao estético, na agonística entre o móvel e imóvel, entre o dialético e o analítico.

$\mathrm{O}$ artístico e o plural são, portanto, relevantes para uma alternatividade de criação de modos de vida extraordinários, que virão não só ao conhecimento sublime, mas a cativar o ético e o emotivo social como alternativa às rotinas disciplinadas e como possível rumo a um futuro progressista de cunho humano, não apenas tecnológico.

\section{8) O esperado e o oportuno v. o inesperado e o inoportuno - ciclo agonístico da ortodoxia e da heterodoxia}

Neste tópico se discursa sobre as artes sociais e políticas, a projeção do futuro e qualidades de opiniões. Pode-se dizer que convenções sociais se amparam em dois conceitos retóricos: do esperado, provável (eikós) (ARISTÓTELES, 2011, p. 49, p. $206^{20}$ ) e do oportuno (kairós) (PLEBE, 1978, pp. 6-8). Em um conhecimento humano, embora se possa ter uma aparência analítica, com face de universalidade e eternidade, tal estabilidade é retórica. Há aquilo que é esperado e um dado senso de perenidade. Pois uma analítica humanista não apaga de todo a dialética, que permanece dormente em um dado curso histórico. Num tempo oportuno, um tópico estável pode vir a ser revisitado. Ou seja, se há um ciclo filosófico, é esta relação discursiva entre o móvel e o imóvel, de transição dialética e analítica. Pois se a imitação é a cópia tradicional, a emulação é transmutação de valores contingentes e pouco novos, no mais mantida a essência dos sujeitos e coisas, a invenção pode trazer mais inovação do que repetição. Assim, se formula um círculo filosófico em que vontades e emoções (páthos) formam um nicho com costumes intelectuais e materiais (éthos), e tais costumes se desdobram em razões para instituição de acordos e normas (itens 5, 6 e 7), produzido

uso de argumentos com ênfase em uma das três abordagens (nicho; lógica/comparação; vontade/afetação), por combinação de ênfaseemduas, ou mesmo nas três.

20 Cf. 1357a35-1357b1 e 1402b20-1403a4. Resume-se pelo seguinte: probabilidade é aquilo que ocorre usualmente, mas não sempre. Qualquer argumento baseado no que ocorre usualmente se mostra sempre vulnerável à refutação, pois, como não se fundamenta no necessário, nem no que ocorre sempre, resta uma margem para dúvida e, assim, para diálogo. 
conhecimento natural ou artificial (item 4). Passado um tempo de estabilidade, este ciclo se renova.

É em um momento revolucionário, de movimentação social, que viceja material para a filosofia do discurso, a retórica. A invenção passa a ter um papel fundamental para o progresso, para se manter o estado de coisas, ou para o regresso humano - uma oportunidade histórica é o gatilho para o ponto mais alto da agonística social, por reorganização tribal ética, e como serão distribuídos os valores e poderes. A emulação e a imitação já não bastam com sua rede de respostas e de vida ética. $O$ movimento social pede uma nova lógica e analógica. Idem, pode pedir uma alteração ética, ou reconhecimento ético: de insumos, de indumentárias, de arte, arquitetura, de estética, de comportamentos esperados e oportunos no ambiente gregário; pode pedir uma alteração emotiva, ou reconhecimento emotivo: discursos para sanar a ânsia por uma futurologia das emoções explicadas racionalmente, ou irracionalmente, e para resolução da sensação de perdimento do "onde" e do "como" o sujeito se encontra com aqueles os quais se identifica ética e emotivamente, na nova configuração. E aqueles que passam a reconhecer um nicho diferente como possível também passarão por uma adaptação emotiva, num perdimento entre aceitação e refutação, e por quais argumentos/valores corroboram para se compreender a outra perspectiva ou por quais razões/valores rechaçá-la. Enfim, pedem-se discursos que expliquem, lógica e comparativamente, os movimentos dos nichos e de afetações ${ }^{21}$.

Diga-se, aí, que as forças sociais e políticas que querem regredir precisam inventar, principalmente através de uma linguagem ética laudatória, um "novo" éthos e um "novo" páthos para que seja, essencialmente, a mesma coisa de uma política social anterior, saudosista. Mudam-se as contingências, as cores das palavras do discurso, mas a essência é a mesma. Os que querem o estado de coisas, precisam apenas argumentar reacionariamente contra a rapidez e o risco da heterodoxia progressista. O fundamento conservador nem sempre é ortodoxia ${ }^{22}$, mas pode ser

21 Estas ideias são inspiradas no tópico nuclear trazido por Kuhn, na obra já citada: surge um paradigma científico, que tem uma vitalidade estável para a solução de quebra-cabeças, até que comece a se degradar. Disso, se inicia um tempo de instabilidade, de competição de discursos científicos, até que, da revolução, surge um novo paradigma. Kuhn propõe que esse ciclo seja explicação da estrutura das revoluções científicas. Evidente que estes ciclos nem sempre são tão bem marcados como Kuhn descreve, mas é de se captar a ideia do autor, de modo que estas revoluções ocorrem em diversos assuntos distintos, de maneira misturada e ao mesmo tempo, com disputas argumentativas, de valores e de afetos.

22 Deorthé dóxa.Significa opinião correta, verdadeira. Neste artigo, ortodoxas políticas são opiniões que logram se estabelecer como acordos sociais tanto de base quanto de política institucional, a partir de 
opinião (dóxa) já existente e conhecida - alguma logética do passado ou do presente. Note-se que também é possível que a heterodoxia progressista também se torne ortodoxa em um futuro. Para regressistas e conservadores, basta, por exemplo, um enfoque emotivo no medo de um futuro caótico e no desencontro que decorrerá do perdimento das tradições das tribos sociais. Já os que visam a progredir, precisam passar por uma série retórica muito fina e sublime, que consiste no convencimento de que o ético, probatório lógico e analógico, e emotivo já produz no presente, e provavelmente produzirá no futuro, uma política de costumes laudatórios, racional e de valores melhores que os passados e presentes.

Propõe-se que as dificuldades da arte e da cultura estão na criação de subjetividades com história de origem e na projeção de valores e emoções para fora do nicho identitário. Significa fazer o outro compreender uma identidade distinta, às vezes até nova demais, em seu saber-fazer, seus valores e suas emoções e, ainda, aprová-las. Isto demanda desafiar o que ou é logética consolidada ou uma ortodoxia política, que se espera ordinária e retoricamente massificada, no mais, pelo recurso retórico da sinédoque (tomar a parte pelo todo - a maioria equivale, retoricamente, ao todo). Interessa politicamente aos corpos políticos vitais, desde seus poderes de base, uma arte e uma cultura controladas e sinédoque (tomar parte pelo todo) auxilia na formação de uma massa simbólica. Os nichos sociais se convertem simbolicamente em nichos de mercado ou em representações da maioria. Ou a arte é para se vender para muitos ou conquistar grande parte, ou não existe. É útil a alguns grupos que se lançam ao geral, por sinédoque, a invenção de que há um só povo, uma massa homogênea. Se num discurso popular a sinédoque é efetiva, na ciência e na filosofia uma identidade generalizada idealista inventada por uso de retórica se constrói por uso de método formal lógico dedutivo. Em suma, para sinédoque ou para uma lógica artificial, tudo deve se formar a partir da forma da maioria, que é representativamente o "todo". Inventa-se crença em que, se há nichos de povo que não são iguais à maioria, deveriam ser. Ora, note-se esta falaciosa representação do real, não obstante eficaz enquanto discurso artificial.

Os simulacros culturais válidos são espelhos de si e os dos outros são para se adequarem, apenas por sua heterodoxia, por sua diferença e o incômodo que isto causa. Porque do contrário frustra-se o esperado retórico, por estranhamento ético e emotivo,

afirmações (item 6). São afirmações que deixam de ser dialéticas para se tornarem analíticas, embora não sem apagar uma dialética social, mais ou menos visível. 
mais do que por aprofundamento investigativo. O ético e o emotivo ganham aparência de analítico lógico e comparativo, ou procuram um discurso científico/filosófico para se legitimarem. Nenhuma verdade pode ser diferente da posta pelo "eu" ou "meu grupo". Essa adequação artificialmente coercitiva é recurso retórico tarimbado de regressistas e conservadores para grosar o progresso antes de qualquer dialética possível. A arte induz o sujeito a pensar essa filosofia popular dos prejuízos. Acreditase, quase que religiosamente, ser mais seguro, prudente, organizado, disciplinado, voltar reiteradamente ao passado, que já ocorreu o trouxe o povo até aqui, e repetir o passado no presente, com poucas modificações contingentes e talvez algumas de essência. A arte inventiva tem essa capacidade de inovar no circuito essencial, da cidadania à vida política, mas seus óbices são os maiores e mais difíceis. São perceptíveis obstáculos no jogo: opinião do passado, opinião do presente e opinião do futuro. Há dóxas já estabelecidas, as tidas como ortodoxas, e as não estabelecidas, heterodoxas. Por movimentos sociais e políticos se faz com que opiniões presentes se tornem passadas, e que as passadas sejam memória histórica e que novas opiniões surjam e se estabeleçam como acordos estáveis ou saberes de ciências naturais. Eis, novamente, um ciclo.

\section{9) Riscos e acertos - o papel da arte nos ensaios culturais sociais: possíveis ensaios de bases políticas e críticas à proposta de invenção}

Não é toda ou qualquer arte de formular discursos sociais e políticos que logra o otimismo progressista veiculado aqui, pois a falsificação e a convivência de contradições são traços antiéticos e ilógicos, mas possíveis. Antiética (hostilizações) e contradições substanciais (inversões de discurso, conforme conveniência de vontade momentânea) são traços de alguns nichos sociais que também são capazes de reinventar o passado e de inventar o presente. A invenção retórica existe, mas tem existência do tipo "ser". Fiscalização e contraposição cabe a outros intentos artificiais competitivos, de sorte que cada nicho ético e lógico/comparativo possa arguir sobre o “dever ser" para si.

A arte discursiva sobre o presente e o futuro tem condições de iluminar, oferecer uma materialização de percepções do espírito vital e do corpo vivo ao público plural, não só de percepção simplista de uma maioria e deferência incondicional a ela. A arte discursiva sobre o passado deve ser bastante cautelosa, pois é capaz de reduzir fatos e feitos antiéticos a ações de orgásmicas cruzadas-nibelungas. A capacidade para 
reinventar interpretativamente o passado é limitada, pois já há causas - sujeitos, fatos, feitos - e consequências consumadas. No presente, as consequências se consumam diariamente. No futuro, são incertos os sujeitos, fatos e feitos, e consequências. Reinventar o passado pode implicar, por exemplo, em assassinos serem exaltados como heróis e, contraditoriamente, religiões fundadas no amor se aliarem a tais grupos no presente.

São traços daquilo que Eco chama de Fascismo Eterno (ECO, 2019, pp. 39-41; p. 45). Sujeitos de valores "a", "b", "c", passam a ignorar (ou serem forçados a ignorar) seus valores essenciais "a", para se juntarem a sujeitos de valores "b", "c", “d”, inclusive sendo aceitáveis contradições de valores. Ainda no trecho citado, Eco diz que até podem se unir partidos sem qualquer identidade de bandeiras, sendo contraditórios entre si. Estes partidos apenas caminham juntos devido ao símbolo de uma união nacional homogênea, criado pelo discurso retórico fascista, razão usada como via de fazer parte de um poder totalitário. Há, portanto, uma fragmentariedade hipócrita, atuada, de valores em jogo numa ideologia que visa fazer todas se submeterem a ela. Seu método essencial é antiético - eliminar violentamente, coercitivamente, toda a possibilidade de que haja nichos alternativos. Considere-se que na ideia de impossibilidade de mistura de bandeiras substanciais, essenciais, pode estar a Gaia da resistência e da disputa por espaço vital ético/afetivo. Há éticas imiscíveis, que só se misturam por cessões substanciais que podem levá-las a se tornar algo oposto em relação a valores originalmente defendidos. E, depois, ainda se buscar recuperar os valores que foram repelidos ou ignorados, já sem a credibilidade de antes. Nunca se sabe bem as bandeiras e argumentos, que não simplesmente mudam, mas se invertem ao alvedrio da vontade de poder. Arthur Blair, mais conhecido como Orwell, chama a aceitação deste agir contraditório de "duplipensamento" (ORWELL, 2009, p. 48). Esta falta de consciência filosófica de si foi erro substancial de certo partido nacional, por exemplo. Chegou-se ao poder, unindo-se a outro partido de ideias opostas, e abriu-se mão da arte de resistir.

Disso há de se perceber que a questão da tolerância a contrariedades é notação para o niilismo, um esvaziamento substancial de valores éticos. O sujeito que é de um éthos pode ir a outro e se misturar. Faz aliados de seus opositores no objeto de oposição, à abstração rápida e sucessiva de valores essenciais. Os valores pelos quais se advoga ora são, ora não são. Os valores estão conforme a conveniência da vontade sem ética e sem razão/comparação, e o que importa é, daí, a vontade pura de poder. É 
apenas satisfazer as necessidades diárias, de preferência com muito luxo. A ética passa a ser e não ser ao mesmo tempo, o sujeito fragmentário tem duas ou mais agendas de vida e elas se contradizem além da urbanidade de uma tolerância diária. Trata-se de um sincretismo em que se misturam contradições. As pistas para esses lançamentos dissimulados no jogo retórico social se dão pelos discursos, arte retórica em execução. A arte inventiva merece atenção por ser um ensaio político para a reinvenção do velho, manutenção contingente do atual, e invenção do novo. Se há uma vontade filosófica de eterno retorno de imitação ou emulação do passado e do presente, há, até logicamente, uma resistência competitiva nova na transmutação de valores, que se projeta ao futuro.

Ensaios culturais promovem manifestações éticas/afetivas, que podem ser aventureiras demais. Podem ser antiéticas, nonsenses e repulsivas. Mas podem ser o oposto. A liberdade inventiva é arriscada, pode dar certo ou errado. Mas possibilita a invenção de ensaios políticos substancialmente novos e dar novas escolhas à sociedade, dispondo-a a ser plural e progressista. A arte está alinhada à liberdade e ao extraordinário. E é termômetro para o expressionismo social, que visa a um prestígio logético. Não é surpresa que a liberdade artística incomode o establishment ${ }^{23}$ e o status quo. Porque sujeitos deveriam ser blocos sociais, tudo dentro da experiência possível, esperada, e bem disciplinada (PERELMAN, 2019, pp. 37-38). Um lançamento fora disso pode ser uma bola curva demais e se amplia a vontade de rebatê-la para fora do estádio.

Enfim, a invenção pode ser competitiva, por criar pontos de incômodo ético, lógico/comparativo, afetivo. Tem múltiplos gumes, alguns úteis e outros nocivos. Esta face problemática revela, conforme o dito no item 6 , a qualidade política e dialética da coisa. Uma ideologia totalitária visa a eliminar a dialética para reduzir, retoricamente, a problematicidade política. A redução é artificial, pois a questão continua a existir no pensamento de subjetividades plurais. A redução é forçada artificialmente, por violência humana. Uma invenção pré-histórica, diga-se de passagem.

\section{0) Peroração}

23 Conjunto de ideias dominantes estabelecidas. Contrariadas, repelem mesmo um recalcitrante ético e fundamentado. A ofensa é aos costumes e ao modo de vida dominante. Não se permite arte inventiva onde já se estabeleceu um suposto estabelecimento eterno e digno de alçada universal. Ou o diferente se adapta, ou é marginalizado social e politicamente. 
Invenções retóricas estão no cerne da agonística diária e se lançam à política institucional. O papel de invenções retóricas é fundamental para revoluções e o progresso, pois uma sociedade incapaz de invenções está fadada a repetir o passado e o presente, emulados com novas contingências. O papel político da invenção discursiva é, portanto, o de uma artística, original e arriscada progressão. Pois os inventores progressistas entrarão em dialética não só com os conservadores, mas com regressistas.

Há exercícios práticos, lógicos e comparativos, que podem ser feitos sob o conceito de logética. Há os antiéticos, que apenas se preocupam com seus nichos sociais e usam todo o esforço social para se fortalecerem enquanto facção. Há os românticos, que negam a ciência para se refugiarem em preferências éticas/afetivas e de consumo espiritual ou material, adotada uma impossibilidade de crítica dialética, pois ferir argumentos é tal qual ferir valores e sentimentos. Há os antiéticos, ilógicos/incomparáveis e contrarromânticos, niilistas sem qualquer atrelamento valorativo com o que não seja o si e as próprias necessidades, mas talvez não sem desejos contraditórios de escapar da vida. Enfim, cabe ao leitor escolher sobre experimentar ou não com a arte proposta. Também pode experimentar o fazer discursos em si. Criar, divulgar palavras/imagens que sejam a cara de seu nicho. Expor os conhecimentos diversos, os valores e afetos presentes e futuros de seus nichos. Expor a estética do nicho. É talvez permitir que outros conheçam o nicho publicado e se integrem a ele em identidade de valores, lógica e comparação e afetos. Significa, igualmente, a capacidade de criar nichos novos e vontades novas. Muitas experiências possíveis ao fazer livre, ético, inofensivo, e de afetos positivos para gostos plurais.

Resuma-se, por fim, o que se queria dizer neste artigo: a substância ética, lógica/comparativa e romântica do futuro começa no que fazem alguns artistas do discurso. O progresso e a resistência humana estão, na base, nos ensaios (experimentação, erros e acertos) e publicações da arte discursiva humana. É arte que nos capacita a pensar as metamorfoses da vida, da sociedade e da política, mesmo que indiretamente, por analogia. Nos capacita a encontrar um nicho gregário e emotivo, compreender outras perspectivas e, quiçá, viver uma vida, uma sociedade, uma política extraordinária(s). 


\section{Referências}

ARENDT, Hannah. A Condição Humana. Tradução de Roberto Raposo. 10 a ed. Rio de Janeiro : Forense Universitária, 2007.

ARISTÓTELES. Retórica. Tradução, textos e notas de Edson Bini. $1^{\mathrm{a}}$ ed. São Paulo : Edipro, 2011.

Paulo : Edipro, 2012.

Metafísica. Tradução, textos e notas de Edson Bini. $2^{\mathrm{a}}$ ed. São Ética a Nicômaco. Tradução, textos e notas Edson Bini. $4^{\mathrm{a}}$ ed. São Paulo : Edipro, 2014.

BACHELARD, Gaston. O Novo Espírito Científico. Tradução Antônio José Pinto Ribeiro. Lisboa : Edições 70, 2008.

CÍCERO. On Oratory and Orators. Translated by J. S. Watson. London: George Bell \& Sons, 1896.

La Invención Retorica. Introducción, traducción y notas de Salvador Nuñes. Madrid : Editorial Gredos, 1997.

ECO, Umberto. Fascismo Eterno. Tradução de Eliana Aguiar. $4^{\mathrm{a}}$ ed. Rio de Janeiro : Record, 2019.

KUHN, T. Estrutura das Revoluções Científicas. Tradução Beatriz Vianna Boeira e Nelson Boeira. $5^{\text {a }}$ ed. São Paulo : Editora Perspectiva, 1998.

MEYER, M. A Retórica. Tradução Marly N. Peres. São Paulo : Editora Ática, 2007. Edições 70, 2018

Questões de Retórica: Linguagem, razão, sedução. $1^{\text {a }}$ ed. Lisboa :

ORWELL, George. 1984. Tradução Alexandre Hubner, Heloisa Jahn. São Paulo : Companhia das Letras, 2009.

PERELMAN, Chaïm. Retóricas. Tradução Maria Ermantina Galvão G. Pereira. $1^{\mathrm{a}}$ ed. São Paulo : Martins Fontes, 1997.

; OLBRECHTS-TYTECA, Lucie. Tratado da Argumentação:

A Nova Retórica. Tradução Maria Ermantina de Almeida Prado Galvão, rev. Eduardo Brandão. $3^{a}$ ed. São Paulo : Editora WMF Martins Fontes, 2019.

PLEBE, Armando. Breve História da Retórica Antiga. São Paulo : Ed. da USP, 1978.

Pseudo-Cícero. Retórica a Herênio. Introducción, traducción y notas de Salvador Nuñes. Madrid: Editoral Gredos, 1997.

Pseudo-Longino. De lo Sublime. Traduccíon de Eduardo Molina C. y Pablo Oyarzun R. Santiago: Metales Pesados, 2007. 


\title{
POLITICAL ROLE OF RETHORICAL INVENTION ARTISTIC CREATION AS FOUNDATION OF A PROGRESSIST FUTURE
}

\begin{abstract}
A discourse about rhetorical invention as political preparation. Artistic invention competes with imitation and emulation, of nostalgic tradition and of conservation. The progressist role of art is in projection of subjectivities to social life, and that implies ethical, logical/comparative and emotive formation, beyond the conventional. Hence a probable core of progressist basis and of people's resistance.
\end{abstract}

\section{Keywords}

Rhetorical invention. Art. Politics. 